whole question of the development of higher education in the years ahead. Will the new polytechnics carry out research on a substantial scale, and, if so, who will pay for it? What about the need for more postgraduate education? It is a long time now since the Robbins Commission raised this issue, yet very little has been done. In these and many other ways, the council could become much more vigorous and constructive. It could also in the process help not merely to awaken the interest of the scientific community in its work but also to extend its influence on the development of scientific research in Britain. That, so far, has been a good influence. The need now is that there should be more of it.

\title{
Assessing the AGR
}

Ir has never been easy to feel optimistic about the export prospects of the British nuclear power consortia, committed as they are to the advanced gas cooled reactor. It is clear for a start that the AGR is an expensive piece of equipment compared with an American boiling water reactor. But in the past it has been possible to hope that the greater capital cost of the AGR could be outweighed by its high thermal efficiency and fuel economy. This notion has come under increasing attack since 1965, when an AGR won the contract for Dungeness B power station against competition from a boiling water reactor. And it is clear from the latest annual report of the Kjeller Laboratory of the Norwegian Institutt for Atomenergi that Norwegian companies, at least, are unlikely to be convinced by it.

Since the beginning of 1966 , the institute has collaborated with the Norwegian firm Norsk Hydro on a study of different reactor systems for a $500 \mathrm{MW}$ nuclear power station. A preliminary costing study shows that the AGR is the most expensive type of all. For an AGR of $600 \mathrm{MW}(\mathrm{e})$ the total plant cost would be $£ 43.5$ million, excluding initial fuel charges. (In Britain a similar station would cost more, the report says, because of "the very special requirements of the Central Electricity Generating Board".) Generating costs would be 0.41 pence/KWh. For a boiling water reactor the same size, initial costs would be $£ 34 \cdot 6$ million, and generating costs would be 0.393 pence/ $\mathrm{KWh}$. The other types studied, which included the pressurized water reactor and the heavy water pressure tube reactor, fell in between these two extremes. The fast reactor, the report suggests, would be the cheapest of all, supplying electricity at a cost of 0.264 pence/ $\mathrm{KWh}$, but the figures are admittedly speculative.

In the larger sizes, the gap between the AGR and the BWR narrows slightly; for a 1,000 MW station, generating costs for the $A G R$ would be 0.38 pence/KWh and for the BWR 0.367 pence/KWh. As a result of this study, the institute has decided to carry out a more extensive study to compare the light water boiling reactor with the heavy water boiling reactor.

The UKAEA is inclined to doubt the validity of the assessments. The figures for the AGR, which the AEA itself supplied to the institute, are accurate, but the BWR costs were taken from a catalogue issued in 1964 by the General Electric Company (US). Since then, the AEA says, GE costs are up by $20-30$ per cent; an adjustment of this order would bring the figures into line with the Dungeness B assessment. In any case, although calculations of this sort can give a general feeling for the costs, they are not accurate enough for final decisions to be taken, and the decision to go ahead with the BWR and the heavy water boiling reactor is probably "an unreasonable deduction from the strength of the exercise". Only the discipline of tendering can

really establish costs, the AEA believes; a conclusion shared by the delegates at a recent IAEA symposium in London.

\section{Rescuing the Dragon}

During 1967, the Dragon reactor at Winfrith Heath became the first system to demonstrate the feasibility of high temperature reactors. In the process, it also became the first system in Britain to demonstrate the cliff-hanging financial arrangements of Euratom. The Dragon is a collaborative reactor supported by the countries of OECD; most of the cost falls on the United Kingdom and the Euratom countries. During 1967 Euratom was unable to agree to an extension of the Dragon programme into 1970 , and as a result the UK declared itself willing to bail out Dragon for the whole of 1968 if necessary, to give Euratom more time. Euratom now has two decisions to make; the immediate one is to decide whether to accept the British offer. If Euratom refuses, the UK (together with the other OECD countries not in Euratom) will go ahead for at least one year, and take over the whole project. If Euratom accepts the interim British offer, it will then have to decide, some time next autumn, whether to go on into 1969. If the answer then is yes, Euratom will repay to the UK the share of the 1968 costs; if it is no, then the UK will take full charge of the project. The UK will either get its money back or be left with a project which is almost completely paid for, and is now producing useful information. The UKAEA believes it has a very good deal.

The reactor has operated well, despite a leak which developed in the heat exchangers, allowing helium to leak from the primary to the secondary circuit. The fuel charge developed for the reactor, consisting of particles of thorium and enriched uranium carbides coated with layers of silicon carbide and pyrolytic carbon and contained inside graphite tubes, has worked perfectly, the report says. The fuel reached a temperature of $1,250^{\circ} \mathrm{C}$ and a burn-up of 25 per cent of the uranium-235. A second fuel charge has been developed, with improved particle coatings and graphite, and it has been possible to do without the arrangements for purging the fission products which were incorporated in the first fuel charge. During the year the work of assessment on a full scale power station using the Dragon concept has been continued. One design, called the feed and breed concept, calls for a mixture of fuel. The breed fuel contains fissile uranium-235 and fertile thorium-232 in such proportions that the ${ }^{233} \mathrm{U}$ which is bred replaces the original ${ }^{235} \mathrm{U}$ at the same rate as it is burned. To maintain the reaction, since breed fuel cannot be made critical, part of the core contains highly enriched uranium, the feed fuel. 